Article

\title{
Neuritogenic and Neuroprotective Properties of Peptide Agonists of the Fibroblast Growth Factor Receptor
}

\section{Shizhong Li, Elisabeth Bock and Vladimir Berezin *}

Protein Laboratory, Department of Neuroscience and Pharmacology, Panum Institute, University of Copenhagen, Copenhagen N, Denmark; E-Mails: li@sund.ku.dk (S.L.); bock@sund.ku.dk (E.B.)

* Author to whom correspondence should be addressed; E-Mail: berezin@sund.ku.dk; Tel.: +45-35-32-73-35; Fax: +45-35-36-01-16.

Received: 16 April 2010 / Accepted: 21 May 2010 / Published: 26 May 2010

\begin{abstract}
Fibroblast growth factor receptors (FGFRs) interact with their cognate ligands, FGFs, and with a number of cell adhesion molecules (CAMs), such as the neural cell adhesion molecule (NCAM), mediating a wide range of events during the development and maintenance of the nervous system. Determination of protein structure, in silico modeling and biological studies have recently resulted in the identification of FGFR binding peptides derived from various FGFs and NCAM mimicking the effects of these molecules with regard to their neuritogenic and neuroprotective properties. This review focuses on recently developed functional peptide agonists of FGFR with possible therapeutic potential.
\end{abstract}

Keywords: FGF; FGFR; NCAM; FGFR agonist; neuroprotective effect

\section{Introduction}

\subsection{FGF Receptors}

Fibroblast growth factors (FGFs) exert their effects in target cells by signaling through cell-surface receptor tyrosine kinases. Five FGF receptors (FGFRs), FGFR1-5, have been identified. FGFRs contain three extracellular immunoglobulin (Ig)-like modules, an acidic region located between Ig1 and Ig2, a single transmembrane domain, and an intracellular split tyrosine kinase domain [1]. FGFR5 does not contain an active tyrosine kinase domain. Alternative mRNA splicing results in a number of FGFR splice variants. The third Ig module of FGFR1-3 is encoded by the invariant exon IIIa followed by one of two alternative exons, IIIb or IIIc [2]. Alternate usage of exons IIIb or IIIc affects the 
specificity of FGF binding to FGFRs. For example, FGF7 and FGF10 are known to bind FGFR2 IIIb but not FGFR2 IIIc [3,4].

Binding of FGFs to FGFRs induces FGFR dimerization, leading to receptor autophosphorylation [5]. Autophosphorylation of tyrosine residues in the intracellular domain of FGFR results in the docking of FGF receptor substrate $2 \alpha$ (FRS2 $\alpha$ ), phospholipase-C $\gamma$ (PLC $\gamma$ ), and Src homologous and collagenA (ShcA) and subsequent activation of various intracellular signaling pathways, including the mitogen-activated protein (MAP) kinase, calcium/calmodulin dependent protein kinase, and phosphoinositide-3 (PI3) kinase pathways [6,7].

\subsection{Ligands of FGF Receptors}

\subsubsection{FGFs}

FGFs comprise a large family of 22 structurally and functionally related polypeptide growth factors. In vertebrates, the molecular mass of FGFs ranges from 17 to $34 \mathrm{kDa}$. FGFs possess a central core of 140 amino acids containing 12 antiparallel $\beta$-strands in which the sequence similarity between different members is 30-60\% [8]. FGFs bind heparin and heparan sulfate proteoglycans with high affinity [9]. Several basic amino-acid residues in the $\beta 10-\beta 11$ strands of the growth factors are supposed to be involved in heparin binding [10]. This interaction is hypothesized to be important for FGF stabilization and FGFR activation [11,12].

Among the 22 FGF members, at least 10 are expressed in the brain. FGF1 is predominantly expressed in neurons and is involved in neuroprotection, learning, and memory. FGF2 is expressed in both neurons and astrocytes and is involved in neurogenesis, axonal growth, neuroprotection, and regeneration. FGF1 knockout mice are normal in appearance and behavior [13]. FGF2 knockout mice are viable but exhibit distinct defects in the organization of cortical neurons [14]. Our knowledge of the roles of other FGFs expressed in the central nervous system is currently limited [15]. FGF6 knockout mice are viable, and they display only mild disturbances in muscle regeneration [16]. FGF8 knockout is lethal and is characterized by mid-hindbrain boundary defects [17] and disturbed cerebellar development [18]. FGF8 is also required for the survival of nephrons [19]. FGF9 has been suggested to be a survival factor for medial thoracic and sacral motoneurons and retinal ganglion cells [20,21]. FGF17-deficient mice display disturbed cerebellar development [18].

\subsubsection{Cell Adhesion Molecules}

In addition to the cognate ligands, the FGFs, FGFR interacts with a number of cell adhesion molecules (CAMs), including the neural cell adhesion molecule (NCAM), N-cadherin, L1, neurofascin, and neuroplastin [22-25]. NCAM, N-cadherin, and L1 all promote neuronal differentiation as reflected by neurite outgrowth following homophilic binding to the same CAM expressed on the responsive cell [26]. The possible involvement of FGFR in CAM-mediated induction of neuronal differentiation has been suggested by the observation that a specific tyrosine kinase inhibitor blocked the neurite outgrowth response to all three CAMs at an early stage in the signal transduction cascade. A so-called CAM homology domain in FGFR1 (i.e., a stretch of 20 amino acids residing in the IgII module) has been suggested to be involved in CAM binding [27-30]. This sequence 
is highly conserved between all FGFRs and has sequence homology with $N$-cadherin, NCAM, and L1 [29]. This review focuses primarily on NCAM interactions with FGFR because many of the FGFR peptide agonists have been derived from this molecule.

NCAM plays multiple roles in nervous system development and maintenance [31-34]. NCAM also modulates neuronal plasticity, mediating learning and memory [35-37]. Studies in NCAM knockout mice show that NCAM is crucial for the formation of the olfactory bulb and the mossy fiber system in the hippocampus [38,39]. Polysialic acid (PSA) is a linear homopolymer containing $\alpha 2$, eight sialic acid residues, and NCAM has been shown to be the main PSA carrier in vertebrates. The polysialylated form of NCAM (PSA-NCAM) plays an important role in neural plasticity, including axonal growth, cell migration, synaptic plasticity, and embryonic and adult neurogenesis [40]. Slices prepared from either NCAM knockout mice or mice treated with a PSA-removing enzyme, Endo N, display defects in long-term potentiation (LTP) in the CA1 region of the hippocampus [41].

NCAM is a member of the immunoglobulin (Ig) superfamily (IgSF) and was first described as a synaptosomal membrane protein, termed D2 [42]. NCAM is widely expressed in the developing nervous system and is also found in muscles, heart, kidneys, and gonads. The extracellular part of NCAM is composed of five Ig modules (Ig1-Ig5) and two fibronectin type III (FN3) modules, FN3(1) and FN3(2). In the nervous system three major isoforms are expressed, NCAM-120, NCAM-140, and NCAM-180 (the numbers corresponding to their relative molecular weights), resulting from alternative splicing of a single gene. NCAM-140 and NCAM-180 are transmembrane isoforms that differ in the size of their cytoplasmic domains, whereas NCAM-120 is attached to the membrane via a glycosylphosphatidylinositol (GPI) anchor lacking the cytoplasmic domains [43]. By means of nuclear magnetic resonance (NMR) spectroscopy and X-ray crystallography, the structures of the NCAM Ig1-3, FN3(1), and FN3(2) modules have been determined [44-46].

Direct binding of the two NCAM FN3 modules to the second and third FGFR1 Ig modules has been demonstrated by surface plasmon resonance (SPR) analysis [45]. The NCAM FN3 modules can mimic the neuritogenic activity of the intact molecule [47,48], presumably via interactions with FGFR. Moreover, the second NCAM FN3 module has been shown to induce FGFR1 phosphorylation and promote neurite outgrowth in an FGFR activation-dependent fashion. An NCAM binding site for FGFR1 has been mapped by NMR titration analysis to a region in the second FN3 module [45]. This region also has sequence and structural homology with a part of FGF2.

\section{Peptide Agonists of FGFR Derived from FGFs}

During the past few years, several peptide agonists of FGFR have been identified based on analyses of the interaction interfaces between FGFs and FGFRs as they appear in the crystal structure of the FGF-FGFR complexes. Other FGFR binding peptides have been identified based on analyses of sequence and structure homologies between FGFs and CAMs.

\subsection{Canofins: Peptide Agonists of FGFR Derived from the Canonical FGFR Binding Sites}

According to the crystal structure of the FGF2-FGFR1c complexes, FGF2 forms contacts with Ig2, Ig3, and the interconnecting linker of FGFR1c. The FGF2 residues involved in interactions with Ig2 of the receptor have been shown to be located in the $\beta 1, \beta 2, \beta 3$, and $\beta 12$ strands and in the $\beta 1-\beta 2$ and 
$\beta 8$ - $\beta 9$ loops. The FGF2 residues located in the $N$-terminus, the $\beta 4, \beta 5$, and $\beta 8$ strands, and the $\beta 7-\beta 8$ loop are involved in interactions with Ig3. The FGF2 residues interacting with the Ig2-Ig3 linker interface are located in the $\beta 8-\beta 9$ loop and $\beta 9$ strand [49]. All binding interfaces with FGFR1c are generally located on one side of the FGF2 globular structure (Figure 1, yellow).

Figure 1. A space-filling model of FGF2 (PDB:1CVS). Two $180^{\circ}$ rotation projections are shown. The sequence motifs of hexafin and dekafin are mapped in red and magenta, respectively. The residues constituting the primary and secondary FGFR binding sites [49] are shown in yellow. The figure was made using PyMOL Molecular Viewer (DeLano Scientific LLC, San Francisco, CA, USA).
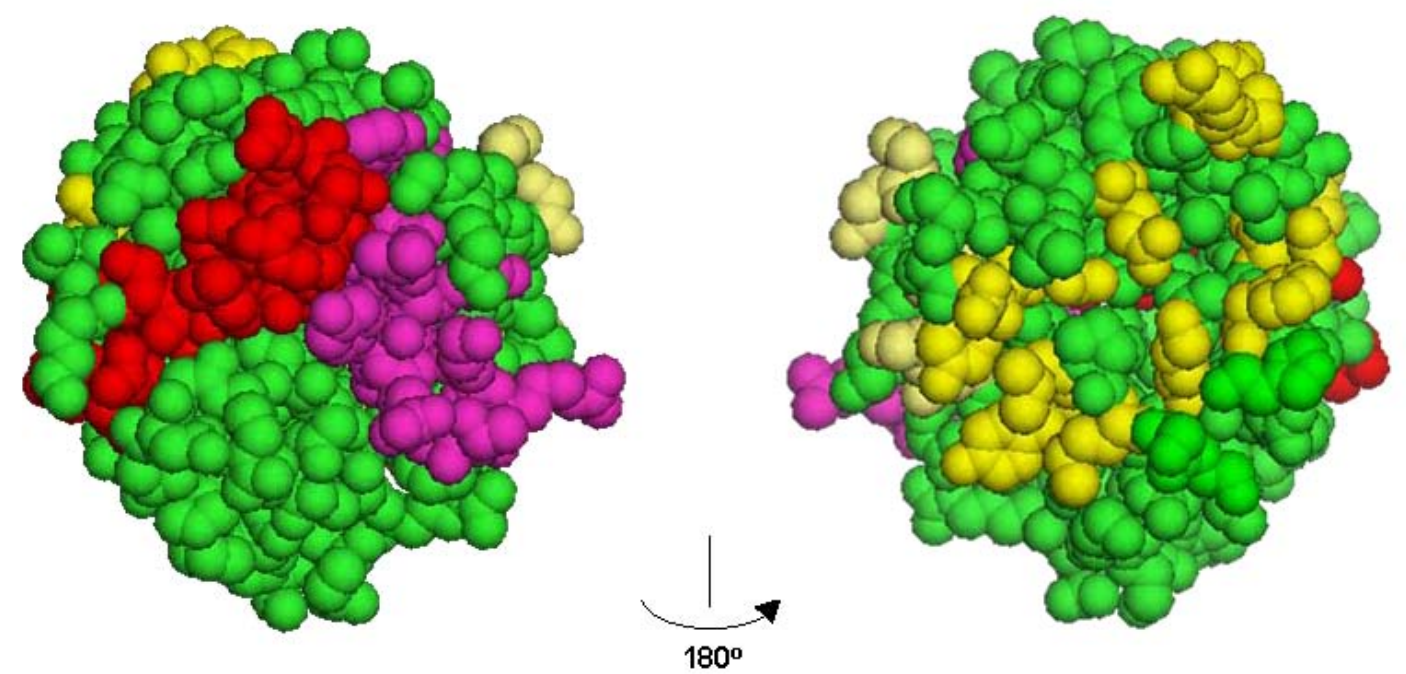

Three peptides, termed canofin1, canofin2, and canofin3, have been derived from the canonical binding sites of FGF2 encompassing the $\beta 1, \beta 2$, and $\beta 11-\beta 12$ loop-strand regions of the growth factor, respectively. The canofin peptides have been demonstrated to specifically bind to FGFR1 and induce FGFR1 phosphorylation. Moreover, phosphorylation induced by the cognate ligand, FGF2, is inhibited by all three canofins, suggesting that these peptides are partial agonists of FGFR [50]. Canofins strongly induce neurite outgrowth from primary cerebellar granule neurons in an FGFR activationdependent manner. They have also been shown to be anti-apoptotic, promoting the survival of cerebellar granule neurons (Table 1). Canofins are regarded as valuable pharmacological tools for the study of the functional roles of specific interactions of FGF2 with FGFR1c [50].

Table 1. Peptide agonists of FGFR derived from FGFs and NCAM.

\begin{tabular}{lllcc}
\hline \multicolumn{1}{c}{ Peptide } & \multicolumn{1}{c}{$\begin{array}{c}\text { Sequence } \\
\text { motif } \\
\text { localization }\end{array}$} & \multicolumn{1}{c}{ In vitro effects } & In vivo effects & Refs. \\
\hline Canofin1, & Interaction & Induction of neurite & N.D. & \\
2, and 3 & sites between & outgrowth by binding to and \\
& FGF2 and & activating FGFR. & \\
& FGFR1 & Protection against apoptosis. & \\
\hline
\end{tabular}


Table 1. Cont.

\begin{tabular}{|c|c|c|c|c|}
\hline Peptide & $\begin{array}{l}\text { Sequence } \\
\text { motif } \\
\text { localization }\end{array}$ & In vitro effects & In vivo effects & Refs. \\
\hline $\begin{array}{l}\text { Hexafin1 } \\
\text { and } 9\end{array}$ & $\begin{array}{l}\beta 6-\beta 7 \\
\text { regions of } \\
\text { FGFs }\end{array}$ & $\begin{array}{l}\text { Binding to and activation of } \\
\text { FGFR. } \\
\text { Protection against apoptosis. }\end{array}$ & $\begin{array}{l}\text { Prolonged retention of social } \\
\text { memory in adult rats. }\end{array}$ & {$[51,52]$} \\
\hline Hexafin2 & $\begin{array}{l}\beta 6-\beta 7 \\
\text { regions of } \\
\text { FGFs }\end{array}$ & $\begin{array}{l}\text { Induction of neurite } \\
\text { outgrowth by binding to and } \\
\text { activating FGFR. }\end{array}$ & $\begin{array}{l}\text { Prolonged retention of social } \\
\text { memory and decreased anxiety-like } \\
\text { behavior in adult rats. } \\
\text { Alleviation of deficits in activity } \\
\text { related to social behavior, including } \\
\text { sociability and social novelty, in R6/2 } \\
\text { mouse model of Huntington's disease. }\end{array}$ & {$[51,52]$} \\
\hline $\begin{array}{l}\text { Hexafin3, } \\
10 \text {, and } 17\end{array}$ & $\begin{array}{l}\beta 6-\beta 7 \\
\text { regions of } \\
\text { FGFs }\end{array}$ & $\begin{array}{l}\text { Induction of neurite } \\
\text { outgrowth by binding to and } \\
\text { activating FGFR. } \\
\text { Protection against apoptosis. }\end{array}$ & N.D. & {$[51]$} \\
\hline Hexafin8 & $\begin{array}{l}\beta 6-\beta 7 \\
\text { regions of } \\
\text { FGFs }\end{array}$ & $\begin{array}{l}\text { Induction of neurite } \\
\text { outgrowth by binding to and } \\
\text { activating FGFR. }\end{array}$ & N.D. & [51] \\
\hline $\begin{array}{l}\text { Dekafin1, } \\
2,3,5 \text {, and } \\
10\end{array}$ & $\begin{array}{l}\beta 10-\beta 11 \\
\text { regions of } \\
\text { FGFs }\end{array}$ & $\begin{array}{l}\text { Induction of neurite } \\
\text { outgrowth by binding to and } \\
\text { activating FGFR. }\end{array}$ & N.D. & [53] \\
\hline $\begin{array}{l}\text { Dekafin6, } \\
8,9 \text {, and } 17\end{array}$ & $\begin{array}{l}\beta 10-\beta 11 \\
\text { regions of } \\
\text { FGFs }\end{array}$ & $\begin{array}{l}\text { Induction of neurite } \\
\text { outgrowth by binding to and } \\
\text { activating FGFR. } \\
\text { Protection against apoptosis. }\end{array}$ & N.D. & [53] \\
\hline DekaCAM & $\begin{array}{l}\beta 10-\beta 11 \\
\text { regions of } \\
\text { FGFs }\end{array}$ & $\begin{array}{l}\text { Induction of neurite } \\
\text { outgrowth by binding to and } \\
\text { activating FGFR. }\end{array}$ & N.D. & [53] \\
\hline FRM & $\begin{array}{l}\text { NCAM/ } \\
\text { FN3(1) }\end{array}$ & $\begin{array}{l}\text { Stimulation of differentiation } \\
\text { and neuroprotection. }\end{array}$ & N.D. & [56] \\
\hline EncaminA & $\begin{array}{l}\text { NCAM/ } \\
\text { FN3(1) }\end{array}$ & $\begin{array}{l}\text { Induction of neurite } \\
\text { outgrowth by binding to and } \\
\text { activating FGFR and } \\
\text { Akt/PKB. }\end{array}$ & N.D. & [55] \\
\hline EncaminC & $\begin{array}{l}\text { NCAM/ } \\
\text { FN3(1) }\end{array}$ & $\begin{array}{l}\text { Induction of neurite } \\
\text { outgrowth by binding to and } \\
\text { activating FGFR and Erk. } \\
\text { Protection against apoptosis. } \\
\text { Enhancement of presynaptic } \\
\text { function. }\end{array}$ & N.D. & [55] \\
\hline
\end{tabular}


Table 1. Cont.

\begin{tabular}{|c|c|c|c|c|}
\hline Peptide & $\begin{array}{l}\text { Sequence } \\
\text { motif } \\
\text { localization }\end{array}$ & In vitro effects & In vivo effects & Refs. \\
\hline EncaminE & $\begin{array}{l}\text { NCAM/ } \\
\text { FN3(1) }\end{array}$ & $\begin{array}{l}\text { Induction of neurite } \\
\text { outgrowth by binding to and } \\
\text { activating FGFR and } \\
\text { Akt/PKB. } \\
\text { Protection against apoptosis. } \\
\text { Enhancement of presynaptic } \\
\text { function. }\end{array}$ & N.D. & [55] \\
\hline FGL & $\begin{array}{l}\text { NCAM/ } \\
\text { FN3(2) }\end{array}$ & $\begin{array}{l}\text { Induction of neurite } \\
\text { outgrowth by binding to and } \\
\text { activating FGFR followed by } \\
\text { activation of ERK1/2 and } \\
\text { Akt/PKB. } \\
\text { Activation of FRS2 } \alpha \text {, ShcA, } \\
\text { and PLC } \gamma \text {. } \\
\text { Protection against apoptosis. } \\
\text { Promotion of synapse } \\
\text { formation. } \\
\text { Enhancement of presynaptic } \\
\text { function. } \\
\text { Attenuation of inflammatory } \\
\text { impact. }\end{array}$ & $\begin{array}{l}\text { Enhancement of spatial and social } \\
\text { memory. } \\
\text { Promotion of postnatal sensorimotor } \\
\text { development. } \\
\text { Protection of hippocampal neurons } \\
\text { against ischemic insult. } \\
\text { Reduction of neuropathological signs } \\
\text { and cognitive impairment in } \\
\text { Alzheimer's disease model. } \\
\text { Modulation of the transcriptional } \\
\text { response to traumatic brain injury. } \\
\text { Attenuation of age-related changes in } \\
\text { long-term potentiation and } \\
\text { inflammatory signs and prevention of } \\
\text { stress-induced dementia. } \\
\text { Induction of large changes in the fine } \\
\text { structure of dendritic spines in the } \\
\text { hippocampus of aged rats related to } \\
\text { improved cognitive function. } \\
\text { Reversal of depression-like } \\
\text { phenotype in NCAM-deficient } \\
\text { animals. } \\
\text { Amelioration of working memory } \\
\text { deficits in rats after neonatal } \\
\text { phencyclidine treatment. }\end{array}$ & $\begin{array}{l}36,45, \\
54,58- \\
68]\end{array}$ \\
\hline BCL & $\begin{array}{l}\text { NCAM/ } \\
\text { FN3(2) }\end{array}$ & $\begin{array}{l}\text { Binding to and activating of } \\
\text { FGFR1. } \\
\text { Stimulation of neurite } \\
\text { outgrowth. }\end{array}$ & N.D. & [69] \\
\hline
\end{tabular}




\subsection{Hexafins: Peptide Agonists of FGFR Derived from the $\beta 6-\beta 7$ Loop Regions of Various FGFs}

The hexafin peptides have been identified based on analysis of the structural homology between a sequence motif in the second NCAM FN3 module involved in NCAM-FGFR interactions, and the $\beta 6-\beta 7$ loop region of FGF2 [45]. All 22 FGFs share homologous sequence motifs located in the $\beta 6-\beta 7$ region [51], and this motif has subsequently been termed the hexafin motif. In the space-filling model of FGF2 in Figure 1 the hexafin motif is marked in red in the $\beta 6-\beta 7$ region. This motif is located on the FGF2 side opposite to the FGF2-FGFR1c binding interface observed in the crystal structure [49]. Hexafins derived from FGF1, 2, 3, 8, 9, 10 and 17 have been characterized and found to bind to FGFR1IIIc and FGFR2IIIb, respectively, with $\mathrm{kD}$ values ranging from $10^{-7}$ to $10^{-8} \mathrm{M}$. Moreover, these peptides have been shown to activate FGFR1-IIIc. Hexafins derived from FGF2, 3, 8, 10, and 17, but not from FGF1 and 9, promote neurite extension, and hexafins derived from FGF1, 3, 9, 10, and 17, but not from FGF2 and 8, promote neuronal survival [51]. Furthermore, in vivo studies show that treatment with hexafin1 and hexafin2 results in prolonged retention of social memory in adult rats, and rats treated with hexafin2 exhibit decreased anxiety-like behavior in the elevated plus maze. Hexafin2 has also been shown to be able to alleviate deficits in activity related to social behavior in the R6/2 mouse model of Huntington's disease (Table 1) [52].

\subsection{Dekafins: Peptide Agonists of FGFR Derived from the $\beta 10-\beta 11$ Loop Regions of Various FGFs}

The dekafin peptides were identified based on sequence homology between a sequence in the first NCAM FN3 module and a sequence motif located in the $\beta 10-\beta 11$ loop regions of all FGFs but FGF19, 21, 22 and 23 (in human). This motif has subsequently been termed the dekafin motif. Dekafins derived from FGF1, 2, 3, 5, 6, 8, 9, 10, and 17 have been characterized and found to bind to FGFR1IIIc and FGFR2IIIb, respectively, with $\mathrm{kD}$ values ranging from $10^{-7}$ to $10^{-8} \mathrm{M}$ [ 52]. Figure 1 shows the model of FGF2 with the dekafin motif marked in magenta in the $\beta 10-\beta 11$ region. Similar to the hexafin motif, the dekafin sequence is located on the FGF2 side opposite to the FGF2-FGFR1 binding interface observed in the crystal structure [49]. A number of basic residues have been shown to be necessary for dekafin1 interactions with FGFR1c. These residues are known to be involved in heparin binding, and heparin analogs have been shown to inhibit dekafin1 binding to the receptor [53]. Dekafin1, 2, 3, 5, 6, 8, 9, 10, and 17 all induce FGFR1c phosphorylation in TREX cells and neurite outgrowth in primary cerebellar granule neurons, although with different potencies. Dekafins are partial agonists of FGFR as reflected by their inhibition of receptor activation induced by the cognate ligand, FGF1. The neuritogenic effect of dekafin1, 2, and 10 has been shown to be sensitive to treatment with a pharmacological inhibitor of FGFR, and dekafin6, 8, 9, and 17 have been demonstrated to be neuroprotective in vitro (Table 1).

\section{Peptide Agonists of FGFR Derived from NCAM}

Interactions between NCAM with FGFR occur through binding of the two most membraneproximal NCAM modules, FN3 modules 1 and 2. Both NCAM FN3(1) and FN3(2) have been shown by surface plasmon resonance analysis to be involved in binding to an Ig2-Ig3 construct of FGFR1 and FGFR2, both splice variant IIIc [54]. A number of synthetic peptides have been synthesized based on 
sequence motifs in the FN3 modules of NCAM and been found to interact with FGFR. The peptide positions are shown in Figure 2.

Figure 2. A space-filling model of the two NCAM FN3 modules. Two $180^{\circ}$ rotation projections are shown. The sequence motifs of EnkaminA, EncaminC, EncaminE, FGL, and BCL are mapped in red, blue, yellow, magenta, and cyan, respectively. The figure was made using PyMOL Molecular Viewer (DeLano Scientific LLC, San Francisco, CA, USA).

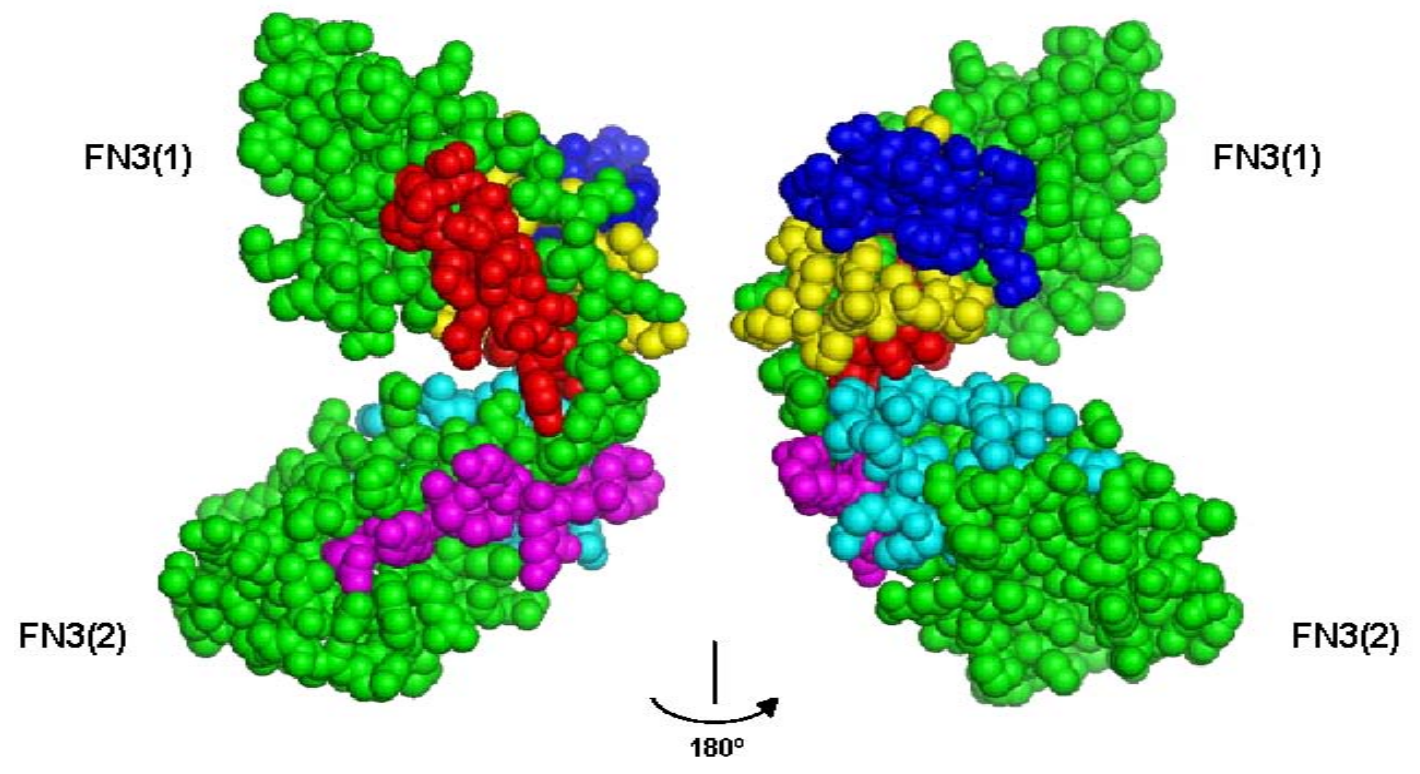

\subsection{Peptide Agonists of FGFR Derived from the First NCAM FN3 Module}

All FN3 modules have a similar topology. Their tertiary structure is composed of two opposing $\beta$ sheets, each containing three to four $\beta$-strands and the interconnecting loops. To identify peptide mimetics with the potential to interact with FGFR, a strand-loop-strand strategy has been used [55]. Following this strategy, six peptides sequentially encompassing the AB-, BC-, CD-, DE-, EF-, and FGstrand-loop-strand regions have been synthesized and tested for their ability to bind FGFR1 and induce FGFR1 phosphorylation. The active peptides derived from the AB-, CD-, and EF-loop regions were termed EncaminA, C, and E, respectively [55]. The active peptide derived from the FG-loop region is termed dekaCAM [53].

EncaminA, C, and E are all located in the $C$-terminal part of the folded NCAM FN3(1) module. They bind to and activate FGFR1. The kD values range from $10^{-8}$ to $10^{-7} \mathrm{M}$. EncaminA and E, but not $\mathrm{C}$, activate Akt/PKB, and EncaminE, but not A and C, activates Erk in primary hippocampal neurons. EncaminC and E, but not A, have been shown to induce neurite outgrowth and promote the survival of cerebellar granule neurons. They also enhance presynaptic function in vitro as reflected by the increased rate of transmitter relaese (Table 1) [55]. The Encamin sequence partially overlaps the FRM motif, which has been previously shown to be able to stimulate neuronal differentiation and neuroprotection [56]. 


\subsection{Peptide Agonists of FGFR Derived from the Second NCAM FN3 Module}

The structure of the second NCAM FN3 module has been solved using NMR spectroscopy (as a single module [45]) and X-ray crystallography (together with FN3[1]) [46]. One of the FN3(2) strandloop-strand regions, the FG loop motif (FGL), has been mapped by NMR titration analysis as an NCAM binding site for FGFR [45].

The FGL peptide has since been the subject of extensive in vitro and in vivo studies, which have established this FGFR agonist as a pharmacological mimetic of various NCAM-related functional modalities (Table 1). FGL has been demonstrated in vitro to bind to and activate FGFR1 and downstream signaling molecules and cascades, such as FRS2 $\alpha$, ShcA, PLC $\gamma$, Akt/PKB, and Erk1/2 [57,58], induce differentiation of primary neurons [45,58], promote neuronal survival [58], promote synapse formation, enhance presynaptic function [36], and attenuate the impact of inflammation [59]. FGL is able to enhance spatial and social memory in normal animals in vivo, promote postnatal sensorimotor development [60], protect hippocampal neurons against ischemic insult [61], and ameliorate cognitive deficits and reduce neuropathological signs in a model of $\beta$-amyloid peptideinduced neurotoxicity, possibly by inhibition of GSK3 $\beta$ [62]. Moreover, FGL has been shown to modulate the transcriptional response to traumatic brain injury [63], attenuate age-related changes in LTP and inflammatory signs [64], and prevent stress-induced dementia, possibly by inducing substantial changes in the fine structure of synapses and dendritic spines in the hippocampus [65,66]. FGL has also been shown to reverse a depression-like phenotype in NCAM-deficient mice and ameliorate working memory deficits in a rat model of schizophrenia [67].

Importantly, the FGL peptide has been shown to rapidly reach the blood and cerebrospinal fluid after systemic administration [60]. FGL has shown no adverse effects in rats, dogs, monkeys (preclinical studies), and healthy human male volunteers [68]. Thus, the pharmacological properties of FGL indicate that this peptide can target neurodegenerative and cognitive disorders.

In addition to FGL, peptides derived from other strand-loop-strand regions in the NCAM FN3(2) module, namely ABL, BCL, CDL, DEL, and EFL, have been synthesized and tested for their capability to bind to FGFR. The BCL peptide was found to be the only peptide that binds to FGFR1 [69]. Similar to FGL, the BCL peptide has been demonstrated to activate the receptor and induce a neuritogenic response. Unlike FGL, however, BCL does not promote neuronal survival [69].

\section{Concluding Remarks}

Identification of binding sites by structural studies or by in silico molecular modeling allows the development of functional agonists or antagonists of cell surface receptors. Thus, peptides derived from FGFR binding site of various FGFs and NCAM have been shown to act as agonists of the receptor, mimicking the functions of these molecules. The effects of the majority of the peptide mimetics presented in Table 1 have been studied using peptides synthesized as dimers or tetramers. A dimer or tetramer promote receptor dimerization and thereby activation. However, mimetic peptides are usually much less potent than the growth factors from which the peptides are derived.

Not very surprisingly, a sequence motif engaged in protein-protein interactions observed in a crystal structure is capable of mimicking the functional activity of the protein when prepared as a synthetic 
peptide. Examples of such peptides are canofins [49]. Unexpectedly, however, in silico molecular modeling has also identified active motifs in FGFs that are located on the side of the growth factors that is opposite to the side shown by X-ray crystallography to be involved in receptor binding. Examples of such motifs are hexafins and dekafins (Figure 1), whose sequences actually are homologous to the canonical binding sites, such as the hexafin and dekafin motifs, see Figure 3. One explanation may be that the hexafin and dekafin motifs are remnants of the evolutionary process due to gene duplication. However, the hexafin and dekafin peptides show the same receptor binding and activation activity as the canofin peptides [51,53]. The non-canonical binding sites in the FGFs may also play a role in FGF interactions with FGFR, probably depending on the specific cellular context. An alternative explanation may be that the non-canonical binding sites in the FGFs serve to preconcentrate the growth factor in close proximity to the FGFRs until it is positioned most favorably for high affinity interactions involving the canonical binding sites. Further studies employing FGF2 mutated on various FGFR binding sites will clarify this issue.

Figure 3. Sequence of human FGF2 with the canofin1, canofin2, canofin3, hexafin, and dekafin motifs marked in blue, green, brown, red, and magenta, respectively. Sequence identities are indicated as a percentage of amino-acid overlap.

1-PALPEDGGSGAFPPGHFKDPKRLYCKNGGFFLRIHPDGRVDGVREKSD
PHIKLQLQAEERGVVSIKGVCANRYLAMKEDGRLLASKCVTDECFFFERL
ESNNYNTYRSRKYTSWYVALKRTGQYKLGSKTGPGQKAILFLPMSAKS-146

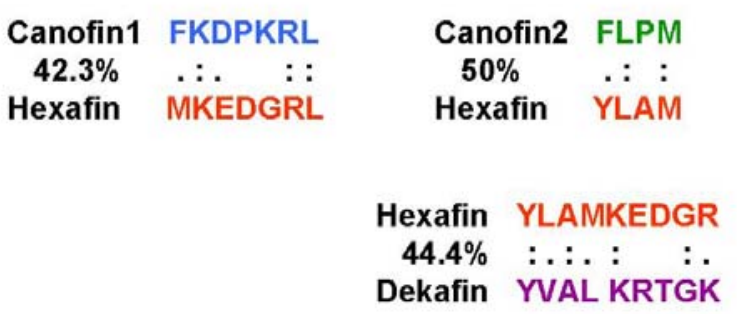

NCAM-FGFR interaction studies reveal multiple binding sites localized on both sides of the interface in the vicinity of the contact between the two NCAM FN3 modules (Figure 2). This implies that one NCAM molecule might concurrently interact with two FGFR molecules, thus promoting receptor dimerization and activation, when NCAM clustering is induced by homophilic NCAM adhesion.

Regardless of the precise roles of multiple FGFR binding motifs in FGFs and NCAM, identification of functional FGFR peptide agonists opens new possibilities for the development of pharmacological tools to study the molecular mechanisms underlying FGFR activation and signaling. Additionally, some of the agonists listed in Table 1 have apparent therapeutic potential.

\section{Acknowledgment}

We would like to thank the Danish Medical and Natural Science Research Councils, the Lundbeck Foundation, the Danish Cancer Society and the European Union-supported integrated project 
PROMEMORIA (FP6 framework-integrated project PROMEMORIA; LSHM-CT-2005-512012) for financial support.

\section{References}

1. Powers, C.J.; McLeskey, S.W.; Wellstein, A. Fibroblast growth factors, and their receptors and signaling. Endocr. Relat. Cancer 2000, 7, 165-197.

2. Goldstrohm, A.C.; Greenleaf, A.L.; Garcia-Blanco, M.A. Co-transcriptional splicing of pre-messenger RNAs: Considerations for the mechanism of alternative splicing. Gene 2001, 277, 31-47.

3. Orniz, D.M. FGFs, heparan sulfate and FGFRs: Complex interactions essential for development. Bioessays 2000, 22, 108-112.

4. Yeh, B.K.; Igarashi, M.; Eliseenkova, A.V.; Plotnikov, A.N.; Sher, I.; Ron, D.; Aaronson, S.A.; Mohammadi, M. Structural basis by which alternative splicing confers specificity in fibroblast growth factor receptors. Proc. Natl. Acad. Sci. USA 2003, 100, 2266-2271.

5. Mohammadi, M.; Olsen, S.K.; Ibrahimi, O.A. Structural basis for fibroblast growth factor receptor activation. Cytokine Growth Factor Rev. 2005, 16, 107-137.

6. Eswarakumar, V.P.; Lax, I.; Schlessinger, J. Cellular signaling by fibroblast growth factor receptors. Cytokine Growth Factor Rev. 2005, 16, 139-149.

7. Dailey, L.; Ambrosetti, D.; Mansukhani, A.; Basilico, C. Mechanisms underlying differential responses to FGF signaling. Cytokine Growth Factor Rev. 2005, 16, 233-247.

8. Zhang, J.; Cousens, L.S.; Barr, P.J.; Sprang, S.R. Three-dimensional structure of human basic fibroblast growth factor, a structural homolog of interleukin 1ß. Proc. Natl. Acad. Sci. USA 1991, 88 , 3446-3450.

9. Burgess, W.H.; Maciag, T. The heparin-binding (fibroblast) growth factor family of protein. Ann. Rev. Biochem. 1989, 58, 575-606.

10. Zhu, X.; Komiya, H.; Chirino, A.; Faham, S.; Fox, G.M.; Arakawa, T.; Hsu, B.T.; Rees, D.C. Three-dimensional structures of acidic and basic fibroblast growth factors. Science 1991, 251, 90-93.

11. Ornitz, D.M.; Itoh, N. Fibroblast growth factors. Genome Biol. 2001, 2, 3005:1-3005:12.

12. Ornitz, D.M.; Xu, J.; Colvin, J.S.; McEwen, D.G.; MacArthur, C.A.; Coulier, F.; Gao, G.; Goldfarb, M. Receptor specificity of the fibroblast growth factor family. J. Biol. Chem. 1996, 271, 15292-15297.

13. Miller, D.L.; Ortega, S.; Bashayan, O.; Basch, R.; Basilico, C. Compensation by fibroblast growth factor 1 (FGF1) does not account for the mild phenotypic defects observed in FGF2 null mice. Mol. Cell Biol. 2000, 20, 2260-2268.

14. Raballo, R.; Rhee, J.; Lyn-Cook, R.; Leckman, J.F.; Schwartz, M.L.; Vaccarino, F.M. Basic fibroblast growth factor (Fgf2) is necessary for cell proliferation and neurogenesis in the developing cerebral cortex. J. Neurosci. 2000, 20, 5012-5023.

15. Reuss, B.; von Bohlen und Halbach, O. Fibroblast growth factors and their receptors in the central nervous system. Cell Tissue Res. 2003, 313, 139-157. 
16. Fiore, F.; Sebille, A.; Birnbaum, D. Skeletal muscle regeneration is not impaired in Fgf6 -/mutant mice. Biochem. Biophys. Res. Commun. 2000, 272, 138-143.

17. Reifers, F.; Bohli, H.; Walsh, E.C.; Crossley, P.H.; Stainier, D.Y.; Brand, M. Fgf8 is mutated in zebrafish acerebellar (ace) mutants and is required for maintenance of midbrain-hindbrain boundary development and somitogenesis. Development 1998, 125, 2381-2395.

18. Xu, J.; Liu, Z.; Ortitz, D.M. Temporal and spatial gradients of Fgf8 and Fgf17 regulate proliferation and differentiation of midline cerebellar structures. Development 2000, 127, 1833-1843.

19. Grieshammer, U.; Cebrian, C.; Ilagan, R.; Meyers, E.; Herzlinger, D.; Martin, G.R. FGF8 is required for cell survival at distinct stages of nephrogenesis and for regulation of gene expression in nascent nephrons. Development 2005, 132, 3847-3857.

20. Garces, A.; Nishimune, H.; Philippe, J.M.; Pettmann, B.; deLapeyriere, O. FGF9: A motoneuron survival factor expressed by medial thoratic and sacral motoneurons. J. Neurosci. Res. 2000, 60, $1-9$.

21. Kinkl, N.; Ruiz, J.; Vecino, E.; Frasson, M.; Sahel, J.; Hicks, D. Possible involvement of a fibroblast growth factor 9 (FGF9)-FGF receptor-3-mediated pathway in adult pig retinal ganglion cell survival in vitro. Mol. Cell Neurosci. 2003, 23, 39-53.

22. Saffell, L.; Williams, E.J.; Mason, I.J.; Walsh, F.S.; Doherty, P. Expression of a dominant negative FGF receptor inhibits axonal growth and FGF receptor phosphorylation stimulated by CAMs. Neuron 1997, 18, 231-242.

23. Kulahin, N.; Li, S.; Hinsby, A.; Kiselyov, V.; Berezin, V.; Bock, E. Fibronectin type III (FN3) modules of the neuronal cell adhesion molecule L1 interact directly with the fibroblast growth factor (FGF) receptor. Mol. Cell Neurosci. 2008, 37, 528-536.

24. Kirschbaum, K.; Kriebel, M.; Kranz, E.U.; Pötz, O.; Volkmer, H. Analysis of non-canonical fibroblast growth factor receptor 1 (FGFR1) interaction reveals regulatory and activating domains of neurofascin. J. Biol. Chem. 2009, 42, $28533-28542$.

25. Owczarek, S.; Kiryushko, D.; Larsen, M.H.; Kastrup, J.S.; Gajhede, M.; Sandi, C.; Berezin, V.; Bock, E.; Soroka, V. Neuroplastin-55 binds to and signals through the fibroblast growth factor receptor. FASEB J. 2010, 24, 1139-1150.

26. Doherty, P.; Walsh, F.S. Signal transduction events underlying neurite outgrowth stimulated by cell adhesion molecules. Curr. Opin. Neurobiol. 1994, 4, 49-55.

27. Williams, E.J.; Walsh, F.S.; Doherty, P. Tyrosine kinase inhibitors can differentially inhibit integrin-dependent and CAM stimulated neurite outgrowth. J. Cell Biol. 1994a, 124, 1029-1037.

28. Williams, E.J.; Furness, J.; Walsh, F.S.; Doherty, P. Characterisation of the second messenger pathway underlying neurite outgrowth stimulated by FGF. Development 1994b, 120, 1685-1693.

29. Williams, E.J.; Furness, J.; Walsh, F.S.; Doherty, P. Activation of the FGF receptor underlies neurite outgrowth stimulated by L1, N-CAM, and N-cadherin. Neuron 1994c, 13, 583-594.

30. Saffell, L.; Walsh, F.S.; Doherty, P. Expression of NCAM containing VASE in neurons can account for a developmental loss in their neurite outgrowth response to NCAM in a cellular substratum. J. Cell Biol. 1994, 125, 427-436.

31. Rønn, L.C.; Hartz, B.P.; Bock, E. The neural cell adhesion molecule (NCAM) in development and plasticity of the nervous system. Exp. Gerontol. 1998, 33, 853-864. 
32. Rønn, L.C.; Doherty, P.; Holm, A.; Berezin, V.; Bock E. Neurite outgrowth induced by a synthetic peptide ligand of neural cell adhesion molecule requires fibroblast growth factor receptor activation. J. Neurochem. 2000, 75, 665-671.

33. Berezin, V.; Bock, E.; Poulsen, F. The neural cell adhesion molecule NCAM. Curr. Opin. Drug. Disc. Dev. 2000, 3, 605-609.

34. Hinsby, A.M.; Berezin, V.; Bock, E. Molecular mechanisms of NCAM function. Front. Biosci. 2004, 9, 2227-2244.

35. Cremer, H.; Chazal, G.; Carleton, A.; Goridis, C.; Vincent, J.D.; Lledo, P.M. Long-term but not short-term plasticity at mossy fiber synapses is impaired in neural cell adhesion moleculedeficient mice. Proc. Natl Acad. Sci. USA 1998, 95, 13242-13247.

36. Cambon, K.; Hansen, S.M.; Venero, C.; Herrero, A.I.; Skibo, G.; Berezin, V.; Bock, E.; Sandi, C. A synthetic neural cell adhesion molecule mimetic peptide promotes synaptogenesis, enhances presynaptic function, and facilitates memory consolidation. J. Neurosci. 2004, 24, 4197-4204.

37. Sandi, C. Stress, cognitive impairment and cell adhesion molecules. Nat. Rev. Neurosci. 2004, 5, 917-930.

38. Cremer, H.; Chazal, G.; Goridis, C.; Represa, A. NCAM is essential for axonal growth and fasciculation in the hippocampus. Mol. Cell Neurosci. 1997, 8, 323-335.

39. Muller, D.; Wang, C.; Skibo, G.; Toni, N.; Cremer, H.; Calaora, V.; Rougon, G.; Kiss, J.Z. PSANCAM is required for activity-induced synaptic plasticity. Neuron 1996, 17, 413-422.

40. Rutishauser, U. Polysialic acid in the plasticity of the developing and adult vertebrate nervous system. Nat. Rev. Neurosci. 2008, 9, 26-35.

41. Muller, D.; Djebbara-Hannas, Z.; Jourdain, P.; Vutskits, L.; Durbec, P.; Rougon, G.; Kiss, J.Z. Brain-derived neurotrophic factor restores long-term potentiation in polysialic acid-neural cell adhesion molecule-deficient hippocampus. Proc. Natl. Acad. Sci. USA 2000, 97, 4315-4320.

42. Jørgensen, O.S.; Bock, E. Brain specific synaptosomal membrane proteins demonstrated by crossed immunoelectrophoresis. J. Neurochem. 1974, 23, 879-880.

43. Walmod, P.S.; Kolkova, K.; Berezin, V.; Bock, E. Zippers make signals: NCAM-mediated molecular interactions and signal transduction. Neurochem. Res. 2004, 29, 2015-2035.

44. Thomsen, N.K.; Soroka, V.; Jensen, P.H.; Berezin, V.; Kiselyov, V.V.; Bock, E.; Poulsen, F.M. The three-dimensional structure of the first domain of neural cell adhesion molecule. Nat. Struct. Biol. 1996, 3, 581-585.

45. Kiselyov, V.V.; Skladchikova, G.; Hinsby, A.M.; Jensen, P.H.; Kulahin, N.; Soroka, V.; Pedersen, N.; Tsetlin, V.; Poulsen, F.M.; Berezin, V.; Bock, E. Structural basis for a direct interaction between FGFR1 and NCAM and evidence for a regulatory role of ATP. Structure 2003, 11, 691-701.

46. Carafoli, F.; Saffell, J.L.; Hohenester, E. Structure of the tandem fibronectin type 3 domains of neural cell adhesion molecule. J. Mol. Biol. 2008, 2, 524-534.

47. Frei, T.; von Bohlen und Halbach, F.; Wille, W.; Schachner, M. Different extracellular domains of the neural cell adhesion molecule (N-CAM) are involved in different functions. J. Cell Biol. 1992, 118, 177-194.

48. Kasper, C.; Rasmussen, H.; Kastrup, J.S.; Ikemizu, S.; Jones, E.Y.; Berezin, V.; Bock, E.; Larsen, I.K. Structural basis of cell-cell adhesion by NCAM. Nat. Struct. Biol. 2000, 7, 389-393. 
49. Plotnikov, A.N.; Schlessinger, J.; Hubbard, S.R.; Mohammadi, M. Structural basis for FGF receptor dimerization and activation. Cell 1999, 98, 641-650.

50. Manfe, V.; Kochoyan, A.; Bock, E.; Berezin, V. Peptides derived from specific interaction sites of the fibroblast growth factor (FGF) 2-FGF receptor complexes induce receptor activation and signalling. J. Neurochem. 2010, in press.

51. Li, S.; Christensen, C.; Køhler, L.B.; Kiselyov, V.V.; Berezin, V.; Bock, E. Agonists of fibroblast growth factor receptor induce neurite outgrowth and survival of cerebellar granule neurons. Dev. Neurobiol. 2009, 69, 837-854.

52. Rudenko, O.; Tkach, V.; Berezin, V.; Bock, E. Effects of FGF receptor peptide agonists on animal behavior under normal and pathological conditions. Neurosci. Res. 2010, in press.

53. Li, S.; Christensen, C.; Kiselyov, V.V.; Køhler, L.B.; Bock, E.; Berezin, V. Fibroblast growth factor-derived peptides: Functional agonists of the fibroblast growth factor receptor. $J$. Neurochem. 2008, 104, 667-682.

54. Christensen, C.; Lauridsen, J.B.; Berezin, V.; Bock, E.; Kiselyov, V.V. The neural cell adhesion molecule binds to fibroblast growth factor receptor 2. FEBS Lett. 2006, 580, 3386-3390.

55. Hansen, S.M.; Køhler, L.B.; Li, S.; Kiselyov, V.; Christensen, C.; Owczarek, S. Bock, E.; Berezin, V. NCAM-derived peptides function as agonist for the firoblast growth factor receptor. $J$. Neurochem. 2008, 106, 2030-2041.

56. Anderson, A.A.; Kendal, C.E.; Garcia-Maya, M.; Kenny, A.V.; Morris-Triggs, S.A.; Wu, T.; Reynolds, R.; Hohenester, E.; Saffell, J.L. A peptide from the first fibronectin domain of NCAM acts as an inverse agonist and stimulates FGF receptor activation, neurite outgrowth and survival. J. Neurochem. 2005, 95, 570-583.

57. Chen, Y.; Li, S.; Berezin, V.; Bock, E. The fibroblast growth factor receptor (FGFR) agonist FGF1 and the neural cell adhesion molecule-derived peptide FGL activate FGFR substrate $2 \alpha$ differently. J. Neurosci. Res. 2010, 88, 1882-1889.

58. Neiiendam, J.L.; Kohler, L.B.; Christensen, C.; Li, S.; Pedersen, M.V.; Ditlevsen, D.K.; Kornum, M.K.; Kiselyov, V.V.; Berezin, V.; Bock, E. An NCAM-derived FGF-receptor agonist, the FGLpeptide, induces neurite outgrowth and neuronal survival in primary rat neurons. J. Neurochem. 2004, 91, 920-935.

59. Downer, E.J.; Cowley, T.R.; Cox, F.; Maher, F.O.; Berezin, V.; Bock, E.; Lynch, M.A. A synthetic NCAM-derived mimetic peptide, FGL, exerts anti-inflammatory properties via IGF-1 and interferon- $\gamma$ modulation. J. Neurochem. 2009, 109, 1516-1525.

60. Secher, T.; Novitskaia, V.; Berezin, V.; Bock, E.; Glenthoj, B.; Klementiev, B. A neural cell adhesion molecule-derived fibroblast growth factor receptor agonist, the FGL-peptide, promotes early postnatal sensorimotor development and enhances social memory retention. Neuroscience 2006, $141,1289-1299$.

61. Skibo, G.G.; Lushnikova, I.V.; Voronin, K.Y.; Dmitrieva, O.; Novikova, T.; Klementiev, B.; Vaudano, E.; Berezin, V.A.; Bock, E. A synthetic NCAM-derived peptide, FGL, protects hippocampal neurons from ischemic insult both in vitro and in vivo. Eur. J. Neurosci. 2005, 22, 1589-1596. 
62. Klementiev, B.; Novikova, T.; Novitskaya, V.; Walmod, P.S.; Dmytriyeva, O.; Pakkenberg, B.; Berezin, V.; Bock, E. A neural cell adhesion molecule-derived peptide reduces neuropathological signs and cognitive impairment induced by $\mathrm{A} \beta_{25-35}$. Neuroscience 2007, 145, 209-224.

63. Pedersen, M.V.; Helweg-Larsen, R.B.; Nielsen, F.C.; Berezin, V.; Bock, E.; Penkowa, M. The synthetic NCAM-derived peptide, FGL, modulates the transcriptional response to traumatic brain injury. Neurosci. Lett. 2008, 437, 148-153.

64. Downer, E.J.; Cowley, T.R.; Lyons, A.; Mills, K.H.; Berezin, V.; Bock, E.; Lynch, M.A. A novel anti-inflammatory role of NCAM-derived mimetic peptide, FGL. Neurobiol. Aging 2010, 31, 118-128.

65. Borcel, E.; Pérez-Alvarez, L.; Herrero, A.I.; Brionne, T.; Varea, E.; Berezin, V.; Bock, E.; Sandi, C.; Venero, C. Chronic stress in adulthood followed by intermittent stress impairs spatial memory and the survival of newborn hippocampal cells in aging animals: Prevention by FGL, a peptide mimetic of neural cell adhesion molecule. Behav. Pharmacol. 2008, 19, 41-49.

66. Popov, V.I.; Medvedev, N.I.; Kraev, I.V.; Gabbott, P.L.; Davies, H.A.; Lynch, M.; Cowley, T.R.; Berezin, V.; Bock, E.; Stewart, M.G. A cell adhesion molecule mimetic, FGL peptide, induces alterations in synapse and dendritic spine structure in the dentate gyrus of aged rats: A threedimensional ultrastructural study. Eur. J. Neurosci. 2008, 27, 301-314.

67. Aonurm-Helm, A.; Berezin, V.; Bock, E.; Zharkovsky, A. NCAM-mimetic, FGL peptide, restores disrupted fibroblast growth factor receptor (FGFR) phosphorylation and FGFR mediated signaling in neural cell adhesion molecule (NCAM)-deficient mice. Brain Res. 2010, 1309, 1-8.

68. Anand, R.; Seiberling, M.; Kamtchoua, T.; Pokorny, R. Tolerability, safety and pharmacokinetics of the FGLL peptide, a novel mimetic of neural cell adhesion molecule, following intranasal administration in healthy volunteers. Clin. Pharmacokinet. 2007, 46, 351-358.

69. Jacobsen, J.; Kiselyov, V.; Bock, E.; Berezin, V. A peptide motif from the second fibronectin module of the neural cell adhesion molecule, NCAM, NLIKQDDGGSPIRHY, is a binding site for the FGF receptor. Neurochem. Res. 2008, 33, 2532-2539.

(C) 2010 by the authors; licensee MDPI, Basel, Switzerland. This article is an Open Access article distributed under the terms and conditions of the Creative Commons Attribution license (http://creativecommons.org/licenses/by/3.0/). 